\title{
Studi Komparatif Penyediaan Penerjemah Terhadap Penghadap Notaris Tuli Di Indonesia Dan Jepang
}

\author{
Muhammad Reza Hastomo Aji \\ Magister Kenotariatan Fakultas Hukum Universitas Islam Indonesia \\ Jln. Cik Di Tiro No. 1, Yogyakarta, 55223 \\ muhrezaha@gmail.com
}

\begin{abstract}
This study aims to compare the Law on Notary Office in Indonesia (UUJN) with the Law on Notary Office in Japan (Kōshōninhō) in the case that the Notary finds deaf people/communities as their clients, with the first problem formulation, what are the differences between UUJN and Kōshōninhō in providing translators for deaf applicants? Second, how do notaries in Indonesia implement UUJN when they find deaf applicants as their clients ? This is a normative juridical research in which interviewing the informants become additional information in this study. The results of the research conclude that, first, the differences in the provision of translators for deaf Notaries on UUJN and Kōshōninhō are in the condition of applicants, the use of translator phrases, and recognition of deaf people/communities, second, the implementation of a Notary in Indonesia when they find deaf people as clients is by using the services of a sign language interpreter.
\end{abstract}

Key Words: Deaf; interpreter; notary

\begin{abstract}
Abstrak
Penelitian ini bertujuan untuk mengkomparasikan Undang-Undang Jabatan Notaris di Indonesia (UUJN) dengan Undang-undang Jabatan Notaris di Jepang (Kōshōninhō) dalam hal Notaris mendapati kelompok/ masyarakat tuli sebagai kliennya, dengan rumusan masalah pertama,apa perbedaan pada UUJN-P dengan Kōshōninhō dalam penyediaan penerjemah bagi penghadap Notaris yang tuli? kedua, bagaimana Notaris di Indonesia mengimplementasikan UUJN-P ketika mendapati penghadap tuli sebagai kliennya?. Penelitian ini merupakan penelitian yuridis normatif dengan wawancara narasumber sebagai tambahan informasi dalam penelitian ini. Hasil penelitian menyimpulkan bahwa, pertama, perbedaan penyediaan penerjemah bagi penghadap Notaris yang tuli pada UUJN-P dan Kōshōninhō ada pada kondisi penghadap, penggunaan frasa penerjemah, dan pengakuan terhadap kelompok/masyarakat tuli, kedua, implementasi seorang Notaris di Indonesia ketika mendapati penghadap tuli sebagai kliennya yaitu dengan menggunakan jasa seorang juru bahasa isyarat.
\end{abstract}

Kata-kata Kunci: Notaris; penerjemah; tuli 


\section{Pendahuluan}

Pada umumnya sistem hukum negara di dunia ini dikenal dengan 2 macam sistem hukum, yaitu pertama sistem hukum civil law yang berasal dari hukum Romawi, yang kemudian terpecah menjadi 2 kutub yaitu hukum Romawi Jerman, yang dianut oleh negara Jerman, dan hukum Romawi Perancis, yang dianut oleh sebagian besar negara Eropa beserta jajahannya, seperti negara Perancis, Spanyol, Italia, Belanda, termasuk Indonesia dan sistem hukum common law yang berasal dari hukum Inggris, karena itu semua negara yang pernah dijajah atau dipengaruhi oleh Inggris menganut sistem hukum ini, seperti Amerika Serikat, Australia, India, Malaysia, Singapura dan lain-lain¹.

Begitu juga dengan aliran Notaris, pada umumnya dikenal 2 macam aliran yaitu Notaris pada negara civil law yang sering disebut dengan Latijnse Notariat dan Notaris pada negara common law yang pada umumnya disebut Public Notary. Keduanya merupakan suatu jabatan, tetapi mempunyai fungsi dan kewenangan yang berbeda: 'The Latin Notary is a legal professional like an attorney who also prepares documents on behalf of both side in a transaction and ensure that these documents meet the legal requirements of the appropriatejurisdiction", yang diterjemahkan dalam bahasa Indonesia: Latijnse Notariat adalah praktisi hukum yang profesional seperti pengacara yang mempersiapkan dokumen atas nama para pihak dalam suatu transaksi dan memastikan dokumen telah sesuai Undang-undang dan peraturan yang berlaku².

"An American Notary Public is a citizen of high moral character and integrity, who is legally empowered to witness and certify the validity documents and take attestations and depositions. He is not a person who practises law.", yang diterjemahkan dalam bahasa Indonesia: Public Notary adalah seorang warga masyarakat yang mempunyai integritas dan moral yang tinggi untuk menyaksikan dan mengesahkan validitas dokumen dan mengambil pengesahan dan deposisi, bukan seseorang yang berpraktek hukum³.

Negara yang menganut sistem Notaris Latin di antaranya negara-negara benua Eropa (Italia, Prancis, Spanyol, Belanda, Belgia, Portugal), kecuali beberapa Negara Scandinavia, Negara Asia, Afrika, Amerika Lain, Quebec, dan negara Bagian Lousiana di Amerika Serikat. Sedangkan negara yang menganut Notaris common law adalah Amerika Serikat kecuali negara Bagian Lousiana, Inggris, dan

${ }^{1}$ Munir Fuady, Perbandingan Ilmu Hukum, Refika Aditama, Bandung, 2007, hlm. 32.

2 Deborah M. Thaw, "The Notary Public and its Impact in $21^{\text {st }}$ Century", Makalah dalam presentasi di NACO/NACRC Annual Conference, 2000, hlm. 2.

3Pengurus Pusat Ikatan Notaris Indonesia (INI),Jati Diri Notaris Indonesia: Dulu, Sekarang, dan Dimasa Mendatang,Gramedia Pustaka Utama, Jakarta, 2009, hlm. 43. 
sebagian negara di Scandinavia, serta jajahan Inggris di Asia dan Afrika seperti Singapura, Malaysia, Filipina, dan Australia4.

Keberadaan Notaris di tengah-tengah masyarakat hingga saat ini tetap dibutuhkan, Notaris dibutuhkan di dalam bidang hukum keperdataan. Kehadiran jabatan Notaris dikehendaki oleh aturan hukum dengan makud untuk melayani masyarakat yang membutuhkan alat bukti tertulis yang bersifat autentik mengenai keadaan peristiwa atau perbuatan hukum ${ }^{5}$. Notaris merupakan pejabat di mana seseorang memperoleh nasihat yang dapat diandalkan dalam hal pembuatan dokumen yang kuat dalam proses hukum 6 . Mendasarkan pada nilai moral dan nilai etika Notaris, maka pengembanan jabatan Notaris adalah pelayanan kepada masyarakat (klien) yang pengembanannya dihayati sebagai panggilan hidup bersumber pada semangat pengabdian terhadap sesama manusia demi kepentingan umum serta berakar dalam penghormatan terhadap martabat manusia pada umumnya dan martabat Notaris pada khususnya7. Pelayanan dalam hal ini bukan hanya dalam artian "membuat akta", membuat akta hanyalah sebagian dari aktivitas yang disebut pelayanan. Pelayanan menyangkut aspek holistik dan menyeluruh dari mulai kemudahan masyarakat mendapatkan informasi, menghubungi Notaris yang bersangkutan, datang ke tempat Notaris, fasilitas kantor Notaris, keramahan Notaris dan karyawannya ${ }^{8}$ karena adakalanya masyarakat dan/atau kelompok yang datang menghadap dan membutuhkan jasa Notaris ini seorang Tuli, sehingga masyarakat dan/atau kelompok Tuli ini membutuhkan Notaris yang dapat memberikan pelayanan jasa secara maksimal dan dapat mengakomodir hak-haknya sebagai masyarakat dan/atau kelompok Tuli.

Sebagai negara hukum, bangsa Indonesia senantiasa menempatkan penghormatan terhadap harkat dan martabat setiap manusia dalam segala aspek berbangsa, bernegara dan bermasyarakat. Hal ini sebagaimana termaktub dalam konstitusi Undang-Undang Dasar Negara Republik Indonesia Tahun 1945 pada Bab XA Pasal 28 F yang menyatakan bahwasannya "Setiap orang berhak untuk berkomunikasi dan memperoleh informasi untuk mengembangkan pribadi dan lingkungan sosialnya, serta berhak untuk mencari, memperoleh, memiliki, menyimpan, mengolah, dan menyampaikan informasi dengan menggunakan segala jenis saluran yang tersedia", hal tersebut merupakan salah satu jaminan

\footnotetext{
${ }^{4}$ Ibid.

${ }^{5}$ Habib Adjie, Hukum Notaris Indonesia Tafsir Telematik terbadap Undang-Undang Nomor 30 Tabun 20004 tentang Jabatan Notaris, Refika Aditama, Bandung, 2008, hlm. 2.

${ }^{6}$ Muchlis Fatahna dan Joo Purwanto, Notaris Bicara Soal Kenegaraan, Watampone Press, Jakarta, 2003, hlm. 256.

${ }^{7}$ Herlien Budiono, "Notaris dan Kode Etiknya", Makalabdalam Upgrading dan Refreshing Course Nasionallkatan Notaris Indonesia, Medan, 2007, hlm. 3.

${ }^{8}$ Ghansham Anand, Karakteristik Jabatan Notaris di Indonesia, Kencana, Surabaya, 2018, hlm. 110.
} 
dari negara memberikan perlindungan hak konstitusional kepada seluruh warga negara termasuk masyarakat dan/atau kelompok Tuli.

Sebagai bentuk implementasi atas Pasal 28 F Undang-Undang Dasar Negara Republik Indonesia Tahun 1945 tersebut di atas, pemerintah Indonesia mengesahkan Undang-Undang Nomor 8 Tahun 2016 tentang Penyandang Disabilitas. Mencatat laporan dunia tentang penyandang disabilitas yang memperkirakan sekitar $15 \%$ dari penduduk dunia mengalami berbagai bentuk disabilitas, yang mana untuk kawasan Asia Pasifik jumlahnya sekitar 650 juta penyandang disabilitas dan $80 \%$ di antaranya hidup di negara berkembang9 sedangkan laporan PUSDATIN dari Kementerian Sosial (Kemensos) pada 2010 menyatakan bahwa jumlah penyandang disabilitas di Indonesia adalah sebesar 11.580.117 orang dengan perincian data penyandang disabilitas penglihatan 3.474.035, penyandang disabilitas pendegaran 2.547.626, penyandang disabilitas fisik 3.010.830, penyandang disabilitas mental 1.389.614, serta penyandang disabilitas kronis 1.158.01210.

Dengan adanya Undang-Undang Nomor 8 Tahun 2016 tentang Penyandang Disabilitas tersebut seharusnya para masyarakat dan/atau kelompok Tuli saat ini mendapatkan kemudahan dan kebebasan dalam berkomunikasi dan memperoleh informasi dari lawan bicaranya (Pasal 24 Undang-Undang Nomor 8 Tahun 2016 tentang Penyandang Disabilitas) yaitu dengan menggunakan dan memperoleh fasilitas komunikasi berupa bahasa isyarat kepada siapapun termasuk ketika berhadapan dengan Notaris dalam pembuatan akta.

Notaris mempunyai kewajiban untuk memastikan bahwa apa yang termuat dalam aktanya tersebut telah dimengerti dan sesuai dengan kehendak para penghadap dengan membacakannya. Pembacaan akta bukan hanya bermanfaat bagi Notaris namun bermanfaat pula bagi para penghadap, yaitu diantaranya Notaris masih memiliki kesempatan memperbaiki kesalahan-kesalahan yang sebelumnya tidak terlihat. Pembacaan akta adalah kemungkinan terakhir bagi seorang Notaris untuk memeriksa akta yang telah dibuat, selain itu bagi para penghadap manfaat yang diterima adalah para penghadap mendapat kesempatan untuk bertanya tentang hal-hal yang kurang jelas di dalam isi akta, pembacaan akta memberikan kesempatan kepada Notaris dan para penghadap pada detik-detik terakhir, sebelum akta selesai diresmikan dengan tanda tangan penghadap, saksi, dan Notaris untuk melakukan pemikiran ulang dengan kata lain revisi isi akta sehingga tidak terjadi

${ }^{9}$ World Health Organization, World Report on Disability, World Health Organization, Geneva, 2011, hlm. 29.

10"Menakertrans: Buka Kesempatan Kerja yang Luas untuk Penyandang Cacat", https://www.republika.co.id/berita/nasional/umum/12/12/09/merigb-menakertrans-buka-kesempatan-kerjaluas-bagi-penyandang-cacat/, diakses tanggal 4 Juli 2019. 
permasalahan di kemudian hari11. Oleh karena hal tersebut, tentu saja Notaris diwajibkan dapat mencari solusi yang tepat tanpa mengesampingkan hak dari masyarakat/ kelompok Tuli untuk bisa menggunakan fasilitas komunikasi berupa bahasa isyarat dan tanpa mengesampingkan kewajibannya sebagai Notaris untuk membacakan isi akta sebelum penandatanganan akta misalnya dengan menghadirkan seorang penerjemah dalam pembuatan akta tersebut.

Pada penelitian ini penulis memilih untuk melakukan penelitian dengan mengkomparasikan peraturan perundang-undangan sejenis terkait jabatan Notaris dalam penyediaan penerjemah terhadap penghadap Notaris Tuli di Indonesia dan Jepang. Pemilihan Jepang sebagai negara pembanding oleh penulis dikarenakan Jepang merupakan salah satu negara di yang ramah terhadap penyandang disabilitas.

Notaris di Indonesia dalam menjalankan jabatannya diatur dalam UndangUndang Nomor 30 Tahun 2004 tentang Jabatan Notaris yang diamandemen terakhir kalinya dengan Undang-Undang Nomor 2 Tahun 2014 tentang Perubahan atas Undang-Undang Nomor 30 Tahun 2004 tentang Jabatan Notaris (selanjutnya dalam penulisan ini disebut UUJN-P). Sedangkan Notaris di Jepang dalam menjalankan jabatannya diatur dalam Undang-Undang Nomor 53 Tahun 1908 yang telah mengalami beberapa kali amandemen, terakhir dengan UndangUndang Nomor 74 Tahun 2011 tentang perubahan atas Undang-Undang Nomor 53 Tahun 1908 yang disebut dengan Kōshōninhō (公証人法) yang artinya Hukum Notaris $^{12}$ (selanjutnya dalam penulisan ini disebut Kōshōninhō).

\section{Rumusan Masalah}

Berdasarkan uraian tersebut di atas, adapun rumusan permasalahan yang diangkat dalam penelitian ini sebagai berikut: Pertama, apa yang menjadi perbedaan pada UUJN-P dengan Kōshōninhō dalam penyediaan penerjemahbagi penghadap Notaris Tuli? Kedua, bagaimana Notaris di Indonesia mengimplementasikan UUJN-P ketika mendapati penghadap Tuli sebagai kliennya?

\section{Tujuan Penelitian}

Penelitian ini bertujuan: Pertama, Untuk memahami dan mengetahui perbedaan pada UUJN-P dengan Kōshōninhō dalam hal penyediaan penerjemah

\footnotetext{
${ }^{11}$ Erlina Saktiani Karwelo, "Prospek Pembacaan dan Penandatangan Akta Notaris Melalui Video Conference",http://hukum.studentjournal.ub.ac.id/index.php/hukum/article/view/721/70, diakses tanggal 20 September 2019.

12“Undang-Undang Hukum Notaris Jepang”,http://www.japaneselawtranslation.go.jp/law/detail/?ft $\equiv 1 \& \mathrm{re}=2 \& \mathrm{dn}=1 \& \mathrm{x}=0 \& \mathrm{y}=0 \& \mathrm{co}=01 \& \mathrm{ia}=03 \& \mathrm{ja}=04 \& \mathrm{ky}=$ notary\&page $=18$, diakses tanggal 2 Juli 2019.
} 
bagi penghadap Notaris Tuli sehingga diharapkan dapat menjadi bahan guna penyempurnaan UUJN-P di Indonesia; dan Kedua, untuk mengetahui bagaimana Notaris di Indonesia mengimplementasikan UUJN-P ketika mendapati penghadap Tuli sebagai kliennya.

\section{Metode Penelitian}

Penelitian ini merupakan penelitian yuridis normatif dengan wawancara kepada narasumber untuk menambah informasi dalam penelitian ini. Penelitian ini menggunakan pendekatan komparatif (comparative approach). Obyek penelitian ini adalah membandingkan UUJN-P dengan Kōshōninhō dalam penyediaan penerjemahbagi penghadap Notaris Tuli. Narasumber penelitian ini adalah seorang Notaris di Indonesia yang telah berpraktek lebih dari 15 tahun dengan maksud untuk mengetahui pendapat narasumber dalam mengimplementasikan UUJN-P ketika mendapati penghadap Tuli sebagai kliennya. Bahan penelitian yang digunakan terdiri dari bahan hukum primer dan bahan hukum sekunder. Teknik pengumpulan atau pengolahan bahan penelitian dengan studi pustaka dan wawancara. Kemudian penelitian ini dianalisis dari apa yang diungkapkan oleh narasumber dan bahan-bahan hukum yang kemudian disusun secara sistematis dalam bentuk narasi dan selanjutnya diimplementasikan untuk menjawab permasalahan yang diteliti. Kemudian ditarik kesimpulan melalui metode deduktif yaitu cara berfikir yang dimulai dari hal-hal yang bersifat umum kemudian ditarik kesimpulan yang bersifat khusus.

\section{Hasil Penelitian dan Pembahasan}

\section{Analisis Penyediaan Penerjemah Bagi Penghadap Notaris Tuli Pada UUJN-P dan Kōshōninhō}

Berdasarkan hal-hal yang ditelah dipaparkan dalam bab sebelumnya, Notaris di Indonesia dan Notaris di Jepang merupakan Notaris yang menganut sistem hukum civil law yang mana Notaris hanya sebagai pihak yang menerapkan aturan. Pemerintah mengangkat Notaris sebagai orang-orang yang menjadi "pelayan" masyarakat. Sebagai pihak yang diangkat oleh negara, berarti Notaris menjadi wakil negara. Negara melimpahkan kewenangan kepada Notaris untuk melakukan pencatatan dan penetapan serta penyadaran hukum kepada masyarakat, terutama menyangkut hal-hal keperdataan seperti pembuatan perjanjian atau kerjasama ${ }^{13}$. hlm. 11 .

${ }^{13}$ Hartanti Sulihandari dan Nisya Rafiani, Prinsip-Prinsip Dasar Profesi Notaris, Dunia Cerdas, Jakarta, 2013, 
Sebagai seorang Notaris, Notaris di Indonesia dan di Jepang dalam pembuatan suatu akta sama-sama memiliki kewajiban untuk membacakan akta dihadapan para penghadap sebelum para penghadap menandatangani akta tersebut, hal ini dimaksudkan agar isi akta tersebut telah dimengerti dan sesuai dengan kehendak para penghadap. Pembacaan akta tersebut tentunya terdapat manfaat, bagi Notaris sendiri hal ini merupakan kesempatan terakhir untuk memperbaiki kesalahan-kesalahan yang sebelumnya tidak terlihat dan bagi para penghadap hal ini merupakan kesempatan untuk bertanya tentang hal-hal yang kurang jelas di dalam isi akta, sehingga diharapkan tidak terjadi permasalahan di kemudian hari ${ }^{14}$.

Dalam kewajiban pembacaan akta tersebut tentunya tidak menjadi masalah apabila para penghadap bisa mendengar, namun bagaimana jadinya apabila penghadap Notaris tersebut seorang Tuli? Jawaban dari hal tersebut sebenarnya adalah dengan menggunakan jasa seorang penerjemah.

Berdasarkan definisi dari penerjemah itu sendiri, penerjemah adalah orang yang memiliki keahlian untuk melakukan penerjemahan bahasa yaitu dari bahasa sumber ke bahasa sasaran maupun sebaliknya. Bahasa yang dimaksud tersebut dapat berupa bahasa lisan atau tulisan ${ }^{15}$.

Dalam bidang penerjemahan terdapat istilah translation dan interpretation, kedua istilah tersebut maksudnya merupakan cara pengalihan pesan dari bahasa sumber ke bahasa sasaran, namun penggunaannya digunakan pada konteks yang berbeda-beda. Istilah translation mengacu pada pengalihan pesan tertulis dan orang yang melakukannya disebut translator atau penerjemah, sedangkan istilah interpretation mengacu pada pengalihbahasaan dan orang yang melakukannya disebut interpreter atau alih bahasawan ${ }^{16}$.

Penyediaan penerjemah dalam UUJN-P tercantum dalam Pasal 43 ayat (2) yang berbunyi sebagai berikut:

1. Akta wajib dibuat dalam bahasa Indonesia;

2. Dalam hal penghadap tidak mengerti bahasa yang digunakan dalam akta, Notaris wajib menerjemahkan atau menjelaskan isi akta itu dalam bahasa yang dimengerti oleh penghadap;

3. Jika para pihak mengehendaki, akta dapat dibuat dalam bahasa asing;

4. Dalam hal akta dibuat sebagaimana dimaksud pada ayat (3), Notaris wajib menerjemahkannya ke dalam bahasa Indonesia;

${ }^{14}$ Erlina Saktiani Karwelo, Loc. Cit.

${ }^{15}$ Breslin, Richard W, Translation: Application and Research, Gardner Press Inc, New York, 1976, hlm. 3-4.

${ }^{16}$ Rahmi Nur Insani, "Hubungan Membaca dengan Penerjemahan", https://www.kompasiana.com/ rahminurinsani/5dde999f097f363e5475c232/hubungan-membaca-dengan-penerjemahan?page=all, diakses tanggal 25 Oktober 2019. 
5. Apabila Notaris tidak dapat menerjemahkan atau menjelaskannya, akta tersebut diterjemahkan atau dijelaskan oleh seorang penerjemah resmi.

6. Dalam hal terdapat perbedaan penafsiran terhadap isi akta sebagaimana dimaksud pada ayat (2), maka yang digunakan adalah akta yang dbuat dalam bahasa Indonesia.

Sedangkan penyediaan penerjemah dalamKōshōninhō tercantum dalam Pasal 29 yang berbunyi sebagai berikut: "In order to create an instrument in cases where a client does not understand the Japanese language or a client is deaf or mute, or any other person who is incapable of speaking any language and who does not understand written words, notaries must have an interpreter attend the creation of said instrument.",yang diterjemahkan dalam bahasa Indonesia: Dalam pembuatan suatu akta dimana klien tidak mengerti bahasa Jepang atau klien Tuli/ Bisu, atau orang yang tidak mampu berbicara dengan bahasa apapun dan tidak mengerti kata-kata tertulis, Notaris wajib menghadirkan seorang penerjemah pada saat pembuatan akta.

Dengan demikian setelah dilakukan perbandingan penyediaan penerjemah bagi penghadap Notaris Tuli pada UUJN-P dan Kōshōninhō tampak beberapa perbedaan, yaitu: Pertama, ada pada kondisi penghadap, penyediaan penerjemah dalam UUJN-P terjadi ketika kondisi penghadap tidak mengerti bahasa yang digunakan dalam akta yang mana akta tersebut diwajibkan menggunakan bahasa Indonesia, sedangkan penyediaan penerjemah dalam Kōshōninhō terjadi tidak hanya ketika kondisi penghadap tidak mengerti bahasa yang digunakan dalam akta yaitu bahasa Jepang tetapi juga ketika kondisi penghadap itu Tuli, atau orang yang tidak mampu berbicara dengan bahasa apapun dan tidak mengerti kata tertulis. Kedua, penggunaan frasa penerjemah, frasa penerjemah pada UUJNP mengacu kepada translator yang hasil pekerjannya melakukan pengalihan pesan tertulis yang mana melakukan penerjemahan akta dari bahasa Indonesia ke bahasa asing atau sebaliknya yang mana harus memperhatikan kata-kata dan struktur kalimat yang dialihbahasakan dengan teliti agar tidak ada detil yang hilang dari teks bahasa asal, sedangkan frasa penerjemah pada Kōshōninhō mengacu kepada juru bahasa yang pekerjaannya menyampaikan sebuah pesan secara simultan atau langsung dengan akurat dan bukan kata per kata sesuai yang disampaikan oleh penutur. Ketiga, pengakuan terhadap kelompok/masyarakat Tuli, pada UUJN-P penyediaan penerjemah bagi penghadap Tuli pada saat proses pembuatan akta belum diatur, berbeda dengan Kōshōninhō yang secara eksplisit mengatur Notaris untuk wajib menghadirkan juru bahasa bagi penghadap Notaris Tuli. 


\section{Implementasi UUJN-P oleh Notaris di Indonesia Ketika Mendapati Penghadap Tuli sebagai Kliennya}

Berdasarkan karakteristik yang telah ditetapkan oleh penulis sebagai narasumber dalam penelitian ini yang mana adalah seorang Notaris di Indonesia yang telah berpraktek lebih dari 15 tahun, maka terpilihlah Muhammad Firdauz Ibnu Pamungkas yaitu salah satu Notaris di Indonesia yang berpraktek di Kota Yogyakarta sejak 1998, selain itu beliau pada saat ini juga menjabat sebagai Ketua Majelis Pengawas Daerah Notaris Kota Yogyakarta.

Sepanjang kariernya hingga saat ini Notaris Firdauz belum pernah mendapati penghadap Tuli sebagai kliennya, namun beliau memiliki pendapat bahwasannya:

"Mereka masyarakat/ kelompok Tuli dengan keadaannya yang tidak mampu mendengar tidak secara serta merta membuat mereka kehilangan hak keperdatanya, mereka dapat dengan bebas membuat perjanjian dengan siapapun yang dikehendakinya, pada prinsipnya ketika mereka masyarakat/kelompok Tuli ini akan membuat akta tidak perlu memakai pengampuan jika yang bersangkutan masih bisa membaca dan dapat berkomunikasi dengan bahasa isyarat. ${ }^{17 "}$

Pasal 1329 Kitab Undang-Undang Hukum Perdata menyatakan bahwa setiap orang dianggap cakap melakukan perbuatan hukum, kecuali jika yang bersangkutan oleh undang-undang dinyatakan tidak cakap melakukan perbuatan hukum. Mengenai kecapakan seseorang dalam melakukan perbuatan hukum dapat dilihat pada Pasal 330, 433, dan 1330 Kitab Undang-Undang Hukum Perdata. Dari Pasal-pasal tersebut dapat disimpulkan tentang siapa yang cakap melakukan perbuatan hukum. Pada Pasal 1330 Kitab Undang-Undang Hukum Perdata dinyatakan bahwa tidak cakap untuk membuat suatu perjanjian adalah:

1. Orang-orang yang belum dewasa;

2. Mereka yang ditaruh di bawah pengampuan;

3. Orang-orang perempuan, dalam hal-hal yang ditetapkan oleh undangundang, dan pada umumnya semua orang kepada siapa undang-undang telah dilarang membuat perjanjian-perjanjian tertentu.

Mengenai siapa yang dikatakan dewasa sebagaimana ketentuan Pasal 330 Kitab Undang-Undang Hukum Perdata adalah mereka yang belum mencapai umur genap 21 tahun, dan tidak lebih dahulu telah kawin. Apabila perkawinan itu dibubarkan sebelum umur mereka tidak kembali lagi dalam kedudukan belum dewasa.

\footnotetext{
${ }^{17}$ Wawancara dengan Notaris Muhammad Firdauz Ibnu Pamungkas, "Implementasi Ketika Mendapati Penghadap Tuli”, Yogyakarta, 28 Februari 2020.
} 
Sedangkan mereka yang berada di bawah pengampuan sebagaimana ketentuan Pasal 433 Kitab Undang-Undang Hukum Perdata adalah setiap orang dewasa, yang selalu berada dalam keadaan dungu, sakit otak, atau mata gelap harus ditaruh di bawah pengampuan, pun jika ia kadang-kadang cakap mempergunakan pikirannya. Seorang dewasa boleh juga ditaruh di bawah pengampuan karena keborosannya.

Dari isi Pasal-pasal tersebut di atas dapat ditafsirkan secara a contrario bahwa seorang yang Tuli dan telah dewasa tidak termasuk dalam kategori tidak cakap maupun di bawah pengampuan sepanjang undang-undang tidak menentukan lain.

Selanjutnya Notaris Firdauz mengemukakan pendapat bahwa tindakan yang perlu dilakukan Notaris ketika mendapati penghadap Tuli sebagai kliennya:

"Sehingga saat Notaris mendapati kelompok/masyarakat Tuli yang membuat akta kepadanya, maka ketika Notaris menjalankan kewajibannya untuk membacakan dan menjelaskan akta tersebut sebagaimana ketentuan UUJN-P Pasal 16 ayat (1) huruf $m$, Notaris wajib meminta bantuan kepada juru bahasa sebagaimana ketentuan dalam Pasal 43 ayat (5) UUJN-P untuk melakukan penerjemahan ke dalam bahasa isyarat. Selanjutnya dalam teknis pelaksanaannya juru bahasa tersebut berada didekat Notaris kemudian melakukan alih bahasa secara simultan ketika Notaris membacakan atau menjelaskan akta tersebut kepada penghadap Tuli. Selanjutnya setelah akta tersebut dibacakan/dijelaskan oleh Notaris sebagai bentuk antisipasi bahwasannya penghadap Tuli tersebut mengerti/ memahami apa yang telah dibacakan/ dijelaskan Notaris melalui juru bahasa tersebut, Notaris dapat meminta juga penghadap tersebut untuk membaca sendiri dan pada akhir akta, Notaris wajib menyebutkan/ menuliskan bahwasannya kondisi penghadap yang dalam keadaan Tuli, sehingga dalam pembacaan akta tersebut dibantu oleh seorang juru bahasa isyarat. ${ }^{18}$

Dengan demikian berdasarkan pernyataan Notaris Firdauz di atas, maka dapat diketahui bahwa bentuk implementasi UUJN-P oleh Notaris di Indonesia ketika mendapati pengahadap Tuli sebagai kliennya adalah dengan menggunakan jasa seorang juru bahasa isyarat. Dalam pembuatan aktanya ketika Notaris sudah menjalankan kewajibannya untuk membacakan akta tersebut kepada penghadap Tuli dengan bantuan seorang juru bahasa isyarat, Notaris dapat meminta penghadap Tuli tersebut membaca sendiri akta yang telah dibacakan oleh Notaris dan diakhir akta, Notaris wajib menuliskan kondisi penghadap yang Tuli dan dalam pembacaan akta di bantu oleh seorang juru bahasa isyarat. Mereka masyarakat/ kelompok Tuli dengan keadaannya yang tidak mampu mendengar tidak secara serta merta membuat mereka kehilangan 
hak keperdatanya dan tidak perlu memakai pengampuan jika yang bersangkutan masih bisa membaca dan dapat berkomunikasi dengan bahasa isyarat.

Pelayanan jasa Notaris sebagai bagian pelayanan terhadap masyarakat harus dapat menyesuaikan ataupun memenuhi kebutuhan masyarakat. Notaris diharapkan dapat melakukan penafsiran hukum sehingga dapat meningkatkan mutu pelayanan Notaris dan membawa hasil positif bagi masyarakat, dengan demikian bilamana dikaitkan dengan Pasal 24 Undang-Undang Nomor 8 Tahun 2016 tentang Penyandang Disabilitas, jika Notaris menyediakan juru bahasa isyarat dalam pembuatan akta maka masyarakat/kelompok Tuli pada akhirnya dapat terpenuhi haknya untuk menggunakan dan memperoleh fasilitas komunikasi berupa bahasa isyarat dalam berinteraksi.

\section{Penutup}

Berdasarkan hasil penelitian yang sudah dipaparkan di atas, maka dapat diambil kesimpulan bahwa: Pertama, perbedaan penyediaan penerjemah bagi penghadap Notaris Tuli pada UUJN-P dan Kōshōninhō yaitu: 1. ada pada kondisi penghadap, penyediaan penerjemah dalam UUJN-P terjadi ketika kondisi penghadap tidak mengerti bahasa yang digunakan dalam akta yang mana akta tersebut diwajibkan menggunakan bahasa Indonesia, sedangkan penyediaan penerjemah dalam Kōshōninhō terjadi tidak hanya ketika kondisi penghadap tidak mengerti bahasa yang digunakan dalam akta yaitu bahasa Jepang tetapi juga ketika kondisi penghadap itu Tuli, atau orang yang tidak mampu berbicara dengan bahasa apapun dan tidak mengerti kata tertulis. 2. penggunaan frasa penerjemah, frasa penerjemah pada UUJN-P mengacu kepada translator yang hasil pekerjannya melakukan pengalihan pesan tertulis yang mana melakukan penerjemahan akta dari bahasa Indonesia ke bahasa asing atau sebaliknya yang mana harus memperhatikan kata-kata dan struktur kalimat yang dialihbahasakan dengan teliti agar tidak ada detil yang hilang dari teks bahasa asal, sedangkan frasa penerjemah pada Kōshōninhō mengacu kepada juru bahasa yang pekerjaannya menyampaikan sebuah pesan secara simultan atau langsung dengan akurat dan bukan kata per kata sesuai yang disampaikan oleh penutur. Ketiga, pengakuan terhadap kelompok/masyarakat Tuli, pada UUJN-P penyediaan penerjemah bagi penghadap Tuli pada saat proses pembuatan akta belum diatur, berbeda denganKōshōninhō yang secara eksplisit mengatur Notaris untuk wajib menghadirkan juru bahasa bagi penghadap Notaris Tuli. Kedua, selanjutnya implementasi UUJN-P oleh Notaris di Indonesia ketika mendapati pengahadap Tuli sebagai kliennya adalah dengan menggunakan jasa seorang juru 
bahasa isyarat. Dalam pembuatan aktanya ketika Notaris sudah menjalankan kewajibannya untuk membacakan akta tersebut kepada penghadap Tuli dengan bantuan seorang juru bahasa isyarat, Notaris dapat meminta penghadap Tuli tersebut membaca sendiri akta yang telah dibacakan oleh Notaris untuk menghindari miss komunikasi dan diakhir akta, Notaris wajib menuliskan kondisi penghadap yang Tuli dan dalam pembacaan akta di bantu oleh seorang juru bahasa isyarat.

Sebagaimana Undang-Undang Dasar Negara Republik Indonesia Tahun 1945 pada Bab XA Pasal 28 F yang menyatakan bahwasannya "Setiap orang berhak untuk berkomunikasi dan memperoleh informasi untuk mengembangkan pribadi dan lingkungan sosialnya, serta berhak untuk mencari, memperoleh, memiliki, menyimpan, mengolah, dan menyampaikan informasi dengan menggunakan segala jenis saluran yang tersedia" junto Undang-Undang Nomor 8 Tahun 2016 tentang Penyandang Disabilitas Pasal 24 yang isinya "Penyandang Disabilitas Tuli berhak menggunakan dan memperoleh fasilitas informasi dan komunikasi berupa bahasa isyarat dalam interaksi resmi", maka diharapkan materi UUJN-P yang berlaku saat ini, di masa yang akan datang dapat dilakukan amandemen dengan memberikan pengakuan dan penegasan hak bagi kelompok/masyarakat Tuli dengan mewajibkan Notaris untuk menghadirkan juru bahasa isyarat dalam proses pembuatan akta sehingga bagi masyarakat/kelompomTuli mereka mendapatkan jaminan dalam kemudahaan dalam membuat akta dan bagi Notaris mereka dapat memperoleh suatu kepastian hukum dalam melaksanakan pekerjaannya. Selanjutnya dikarenakan pada saat ini belum ada aturan yang mengatur perihal kewajiban Notaris untuk menghadirkan Juru Bahasa Isyarat pada saat pembuatan akta bagi penghadap Tuli dalam UUJN-P, maka diharapkan organisasi Notaris di Indonesia dapat membuat sebuah surat edaran yang mengatur hal tersebut sehingga dapat tercipta keseragaman pelayanan dalam proses pembuatan akta bagi klien Tuli oleh seluruh Notaris di Indonesia.

\section{Daftar Pustaka}

\section{Buku}

Adjie, Habib, Hukum Notaris Indonesia Tafsir Telematik terhadap Undang-Undang Nomor 30 Tahun 20004 tentang Jabatan Notaris, Refika Aditama, Bandung, 2008.

Anand, Ghansham, Karakteristik Jabatan Notaris di Indonesia, Kencana, Surabaya, 2018.

Fatahna, Muchlis dan Joo Purwanto, Notaris Bicara Soal Kenegaraan, Watampone Press, Jakarta, 2003.

Fuady, Munir, Perbandingan Ilmu Hukum, Refika Aditama, Bandung, 2007. 
World Health Organization, World Report on Disability, World Health Organization, Geneva, 2011.

\section{Makalah}

Budiono, Herlien, "Notaris dan Kode Etiknya", Makalah pada Upgrading dan Refreshing Course Nasional Ikatan Notaris Indonesia, Medan, 2007.

Thaw, Deborah M., "The Notary Public and its Impact in 21 ${ }^{\text {st }}$ Century", Makalah dalam presentasi di NACO/NACRC Annual Conference, 2000.

\section{Internet}

Karwelo, Erlina Saktiani, "Prospek Pembacaan dan Penandatangan Akta Notaris Melalui Video Conference",http://hukum.studentjournal.ub.ac.id/index. php/hukum/article/view/721/70, diakses tanggal 20 September 2019.

"Menakertrans: Buka Kesempatan Kerja yang Luas untuk Penyandang Cacat",https:/ / www.republika.co.id/berita/nasional/umum/12/12/09/ merigb-menakertrans-buka-kesempatan-kerja-luas-bagi-penyandangcacat/, diakses tanggal 4 Juli 2019.

“Undang-UndangHukum

Notaris

Jepang", http: / / www.japaneselawtranslation.go.jp /law / detail $/$ ft $=1 \& \mathrm{re}=2 \& \mathrm{dn}=1 \&$ $\mathrm{x}=0 \& \mathrm{y}=0 \& \mathrm{co}=01 \& \mathrm{ia}=03 \& \mathrm{ja}=04 \& \mathrm{ky}=$ notary\&page $=18$, diakses tanggal 2 Juli 2019.

\section{Peraturan Perundang-undangan}

Undang-Undang Dasar Negara Republik Indonesia Tahun 1945.

Kitab Undang-Undang Hukum Perdata Indonesia.

Undang-Undang Nomor 8 Tahun 2016 tentang Penyandang Disabilitas.

Undang-Undang Nomor 2 Tahun 2014 tentang Perubahan atas Undang-undang Nomor 30 Tahun 2004 tentang Jabatan Notaris. 